ppi $201502 Z U 4645$

Esta publicación científica en formato digital es continuidad de la revista impresa ISSN-Versión Impresa 0798-1406 / ISSN-Versión on line 2542-3185Depósito legal pp $197402 Z$ U34
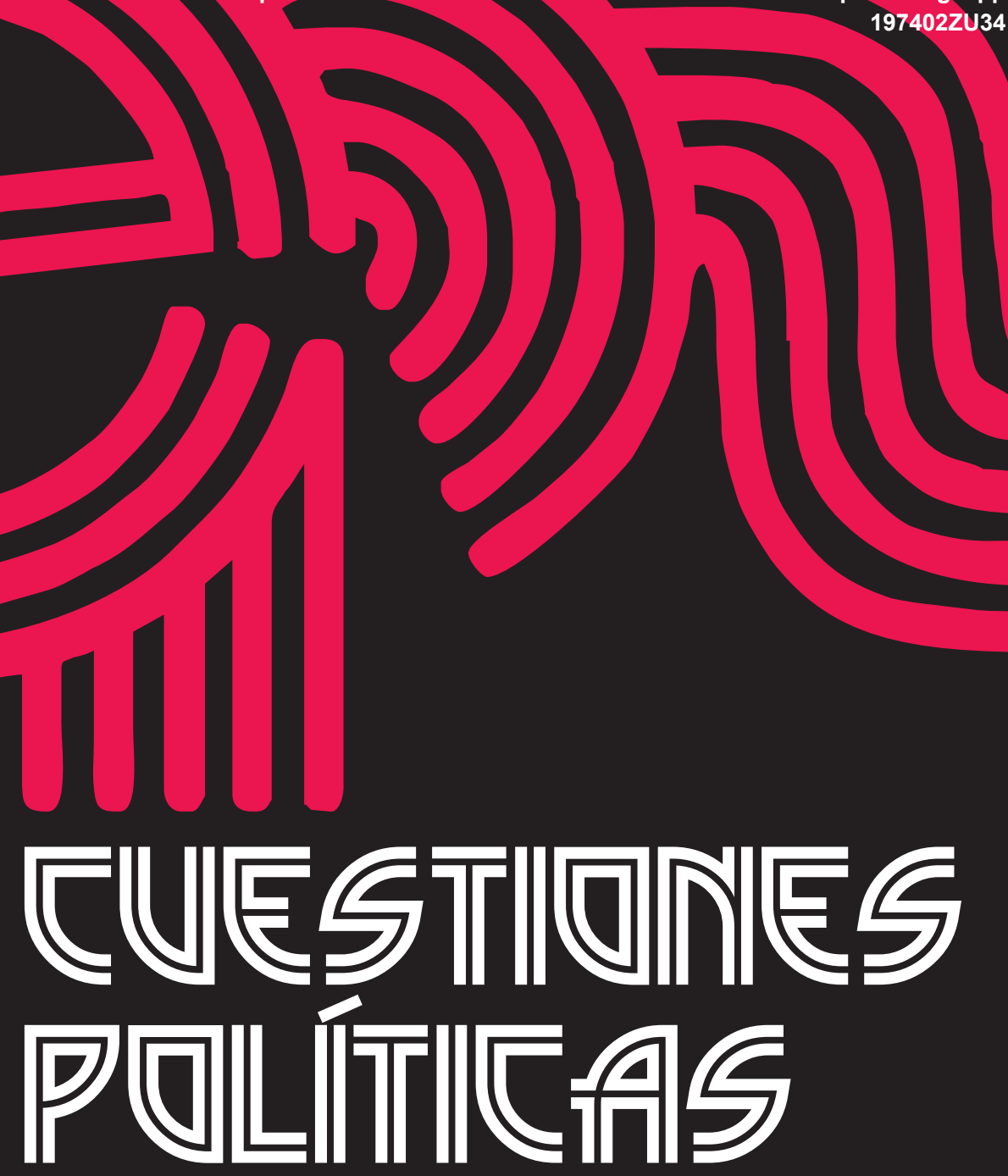

Instituto de Estudios Políticos y Derecho Público "Dr. Humberto J. La Roche" de la Facultad de Ciencias Jurídicas y Políticas de la Universidad del Zulia Maracaibo, Venezuela
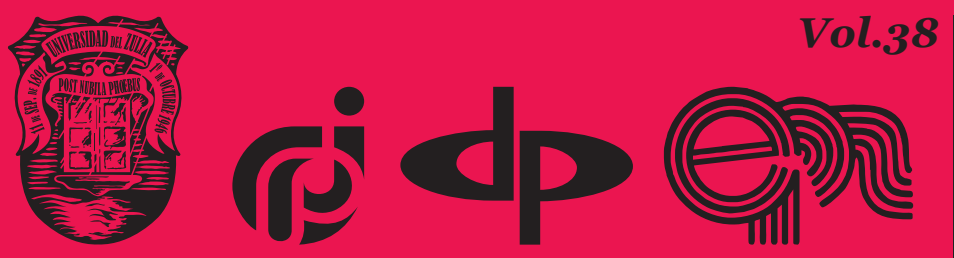

$N^{\circ}$ Especial 2da Parte 2020 


\title{
Political, Military and Technical Cooperation of the Republic of Uzbekistan in the Framework of the Shanghai Cooperation Organization
}

\author{
DOI: https://doi.org/10.46398/cuestpol.382e.14
}

\author{
Marat Zufarovich Galiullin * \\ Farkhad Linarovich Gumarov ** \\ Ramil Rashitovich Kadyrov *** \\ Elvira Imbelevna Kamaletdinova ****
}

\section{Abstract}

The article is devoted to the analysis of the main vectors of technical-military cooperation of the Republic of Uzbekistan within the framework of the Shanghai Cooperation Organization (SCO) in the Central Asia region. The SCO is widely believed to have been part of the Asian version of the North Atlantic Bloc and represents an organization with many areas of activity, where the technical-military cooperation of member countries plays an important role. The main objectives of the organization are to promote peace and stability in one more context, book the development of terrorism, separatism, extremism and drug trafficking, economic cooperation and energy partnership, cooperation and scientific. In made or use of the method anzé of systemic. It is concluded that cooperation in the technical-military field will provide the opportunity for the race to have a greater influence on global political and economic situations, without being abstracted solely from the tasks of the SCO, such as the mutual union of forces of major international organizations. The organization referred to will be in the resolution of various problems, both regionally and globally, to the extent that the talós objectives are consolidated and achieved.

* Candidate of Historical Sciences, Associate Professor of the Department of regional studies and Eurasian studies, Institute of international relations. Kazan Federal University. ORCID ID: https:// orcid.org/oooo-0o02-3798-4328. Email: maratscorpion@yandex.com

** Candidate of History Sciences (PhD in history), assistant, Department of regional and Eurasian studies, Institute of International Relations, Kazan Federal University. ORCID ID: https://orcid.org/oooo0003-0678-0514. Email: Farkhadgumarov@yandex.ru

*** Candidate of Historical Sciences, teacher of the Department of regional studies and Eurasian studies, Institute of international relations, Kazan Federal University. ORCID ID: https://orcid.org/ooooooo3-2996-8288. Email: Kadyrovramil@mail.ru

****Assistant, Department of Regional Studies and Eurasian Studies, Institute of International Relations, Kazan Federal University. ORCID ID: https://orcid.org/oooo-ooo3-3619-6335. Email: elvira-imoiv@ mail.ru 
Marat Zufarovich Galiullin, Farkhad Linarovich Gumarov, Ramil Rashitovich Kadyrov y Elvira Imbelevna Kamaletdinova

Keywords: International relations; Republic of Uzbekistan; Shanghai Cooperation Organization; cooperation between states; Atlantic Alliance.

\section{Cooperación política, militar y técnica de la República de Uzbekistán en el marco de la Organización de Cooperación de Shanghái}

\section{Resumen}

El artículo está dedicado al análisis de los principales vectores de cooperación técnico-militar de la República de Uzbekistán en el marco de la Organización de Cooperación de Shanghai (OCS) en la región de Asia Central. Se cree ampliamente que la OCS se formó como parte de la versión asiática del Bloque del Atlántico Norte y representa una organización con muchas áreas de actividad, donde la cooperación técnico-militar de los países miembros juega un papel importante. Los principales objetivos de la organización son promover la paz y la estabilidad en un contexto más amplio, contrarrestar el desarrollo del terrorismo, el separatismo, el extremismo y el narcotráfico, la cooperación económica y la asociación energética, la cooperación científica y cultural. En hizo uso del método analítico e histórico sistémico. Se concluye que, la cooperación en el ámbito técnico-militar brindará la oportunidad de ejercer una mayor influencia en las situaciones políticas y económicas mundiales, sin abstraerse únicamente de las tareas de la OCS, como la unión mutua de fuerzas de las principales organizaciones internacionales. La organización referida será en la resolución de diversos problemas, tanto a nivel regional como mundial, en la medida que se consolide y logre los objetivos planteados.

Palabras clave: Relaciones internacionales; República de Uzbekistán; Organización de Cooperación de Shanghái; cooperación entre estados; alianza atlántica.

\section{Introduction}

The foundations for political and military-technical cooperation of the SCO member states were 1 aid at the first summits of the organization and had some extension in time. The SCO Secretariat and the Regional Counter-Terrorism Structure (RCTS) were established in Beijing based on the Moscow Summit (28-29 May 2003). The leaders of the participating countries discussed the issues of countering terrorism and extremism: 
The thirty treaties that were signed during this period included the creation of SCO bodies - the Council of Heads of State, the Council of Ministers and the Council of Foreign Ministers. Since 1 January 2004, the SCO has operated as a full-fledged international organization with its own working mechanism, staff and budget (Shanghai Cooperation Organization. New priorities of development, 2015: 56).

The SCO activities consisted mainly of antiterrorist acts, as well as regional movements aimed at preventing separatism and extremism in Central Asia. Some prominent political figures say it is the first international organization to combat terrorism, a new challenge for the military and politicians. The Shanghai Convention on Combating Terrorism, Separatism and Extremism, originally signed by participants in the SCO Founding Summit in Shanghai (2001), introduced for the first time the international concept of separatism and extremism as a criminal act of persecution.

"Aims and purposes include:

- To strengthen cooperation, trust, friendship and good neighborliness among Member States.

- Equality of all Member States, the search for common points of view based on mutual understanding and respect for the views of each of them.

- To promote a broader, new democratic, just, rational political and economic framework.

- To promote greater cooperation in promoting peace, security, and stability in the region.

- Promoting human rights and freedoms in the international obligations of Member States and their national legislation.

- Cooperation in the peaceful settlement and prevention of international conflicts.

- Phased implementation of joint actions in areas of common interest.

- The SCO is not directed against other states and international organizations" (Kurpayanidi and Urmonov, 2016).

\section{Methods}

The methodological basis of research is analysis and synthesis as a general scientific methods of cognition, and historical-systemic and comparativehistorical, historical-typological methods of scientific cognition. 
Marat Zufarovich Galiullin, Farkhad Linarovich Gumarov, Ramil Rashitovich Kadyrov y Elvira Imbelevna Kamaletdinova

Application of comparative-historical method allowed revealing the significance of the integration process in different periods of history, to compare the integration association of the SCO with other acting in the international arena.

The historical-typological method used in the work made it possible to reveal the general course of events. This method has contributed to the identification of causal links between the main political and social problems of the Central Asian region and the need to create security organizations in the region.

In research, the historical and system method was applied. Systemic character of social-historical development means that all events, situations and processes of this development are caused and have a cause-and-effect relation, and are connected among themselves functionally. This approach is applicable to the study of historical processes on the example of the growing popularity of the SCO in the realities of globalization.

\section{Results and Discussion}

The SCO charter establishes a historical link between people. Moreover, the SCO member states have expressed their willingness to promote peace, security and stability in the region, to promote political pluralism and economic globalization. This document ensures SCO cooperation in the field of regional security. SCO combats terrorism and extremism based on legal norms regulating relations in this field, as well as a number of international legal instruments.

International legal documents include: "Convention on Combating Terrorism, Separatism and Extremism" (Shanghai, 15.06.2001)" (The declaration on the Establishment of the Shanghai Cooperation Organization, 2001), which entered into force between the SCO member states, multilateral and bilateral agreements:

1. Agreement on combating terrorism, political and religious extremism, transnational organized crime and other threats to security between Kazakhstan, Tajikistan and Uzbekistan (Tashkent, 21.04.2000) (AlQahtani, 2006).

2. "Agreement between the Government of the Republic of Uzbekistan and the Government of the Republic of Tajikistan on cooperation in combating terrorism, political, religious and other extremism, illicit trade in narcotic drugs and psychotropic substances (Khujand, 26.05.1999)" (The agreement between the government of the republic of uzbekistan and the government of the republic of Tajikistan, 2020). 
3. "Cooperation between China and the Republic of Uzbekistan in combating terrorism, separatism and extremism (Tashkent, 04.09.2003)" (The agreement between the government of the republic of uzbekistan and the government of people's republic of china on cooperation in fight against terrorism, separatism and extremism, 2020).

The SCO member States are focusing on resolving internal conflicts, combating extremism and drug addiction, as well as on establishing a regional anti-terrorist structure.

The policy of the PRC in Central Asia is conditioned by its economic interests, espe-cially the desire to ensure energy security and use of the transit potential of the region. At the same time, it is aimed at maintaining stability and security in the Xinjiang Uygur Autonomous Region. All this caused not only the intensification of ties with the region, but also involvement in the "New Great Game" in Central Asia, where the influence and in-terests of Russia, the United States and the People's Republic of China collide (Sulimanov and Beloglazov, 2018).

Uzbekistan is the foundation of the organization, and the economy and geoscience of the state are in line with the quality of the project. Uzbekistan has become an important instrument in SCO trade, economic, cultural and humanitarian relations, strengthening regional interests, terrorism, extremism and countering aggression.

During the 2004 summit, a Convention on the Elimination of All Forms of Discrimination and Punishment for Drugs and Psychotropic Substances" was signed with a view to SCO and WTO cooperation. Pakistan, India, Iran and Mongolia, the SCO member states are united by a common goal to combat drug trafficking (Shanglin, 2006).

However, Uzbekistan's participation in the SCO has several peculiarities. As the analysis of the Uzbek side's activities within the SCO shows, Tashkent seeks to effectively use the form of SCO to promote its national interests in the international arena, but clearly defends the strategic principle - equal distance from all "centers of power".

The administration of the President of Uzbekistan I. Karimov has learned to use the format of the Shanghai Cooperation Organization and the CIS to send timely information to its partners. For example, at the summit of Shanghai Cooperation Organization in Dushanbe, I. Karimov learned to use the format of Shanghai Cooperation Organization and CIS to send information to their partners in time. Karimov talked about the most severe "Ukrainian events", thus gaining necessary points before Russia. "In the following period, Karimov also used the CIS platform to condemn the actions of the Ukrainian authorities. As a result, these statements of the Uzbek leadership were not in vain, which led to the warming up of the 
Marat Zufarovich Galiullin, Farkhad Linarovich Gumarov, Ramil Rashitovich Kadyrov y Elvira Imbelevna Kamaletdinova

Uzbek-Russian relations, which were previously overshadowed by the plans of Tashkent to acquire weapons from NATO countries" (Frolenkov, 2008).

On the one hand, the Shanghai Cooperation Organization as a mechanism for economic cooperation does not seem particularly attractive to Tashkent. Uzbekistan has always relied and continues to rely fully on bilateral format to address important issues. In addition, the Uzbek side has blocked unwanted projects and initiatives in the economic sphere. Thus, last year Uzbekistan, using the right of its chairman, sharply rejected the proposal of the Chinese side to establish a free trade zone within the SCO. "Uzbekistan is not ready to consider a proposal to establish a free trade zone within the Shanghai Cooperation Organization" (Uzbekistan is not ready to consider the proposal to create a SCO FTA, 2020).

Since Uzbekistan's last withdrawal from the CSTO, Tashkent has always demonstrated and consistently focused its attention on establishing relations with bilateral partners. For instance, in addressing important issues for SCO member nations, the Uzbek side adopted bilateral format.

Since Uzbekistan's last withdrawal from CSTO, Tashkent has always demonstrated and consistently focused on the systematic establishment of relations in bilateral format. Thus, in decisions on important issues for SCO member nations, the Uzbek leadership has remained loyal to its general line of bilateral cooperation.

\section{Summary}

Over the past years, the presidency of the Republic of Uzbekistan in SCO 2015-2016 was marked by a complex of progressive initiatives and actions to strengthen the meaning and status of this organization in the international arena.

First, the Republic of Uzbekistan has initiated a set of measures to increase the efficiency of SCO activities, improve the decision-making apparatus that exclusively meets the goals, objectives and basic principles of the organization. In this regard, special significance is attached to the establishment of a multipolar dialogue and ties between SCO and other status international organizations.

The organization's networking with the UN is a prime example of this. Back during Uzbekistan's, second presidency of SCO, namely in December 2009. The UN General Assembly adopted the "Resolution on Cooperation between the UN and SCO". A useful fusion of positive experience of these two international organizations has contributed to obtaining qualitatively new opportunities in maintaining and preserving international and regional security. 
Secondly, it was at the suggestion of the Republic of Uzbekistan that the "Joint Declaration on Cooperation between the SCO and UN Secretariats" was signed during the visit of UN Secretary General Ban Ki-moon to Uzbekistan in April 2010. Thus, at the ceremony dedicated to the signing of this weighty legal act, "UN Secretary General commended the Republic of Uzbekistan in the framework of its presidency of the Shanghai Cooperation Organization. He noted the fact that this guide was extremely important for maintaining peace and security, as well as for addressing pressing regional issues within the framework of international cooperation as a whole" (Uzbekistan 's initiatives and their role in strengthening the Shanghai Cooperation Organization, 2010).

The above-mentioned Declaration was the foundation, potential for increasing the ways of cooperation in such strategic areas as prevention and elimination of conflicts, fight against terrorism, non-proliferation of weapons of mass destruction, maintenance of stable economic development, search for ways to solve environmental pollution problems and others.

\section{Conclusions}

According to foreign experts in the field of political science, cooperation in the military-technical field will provide an opportunity to exert a stronger influence on global political and economic situations, without abstracting solely from the tasks of SCO, as the mutual union of forces of leading international organizations. It will have a more effective and widespread affected the resolution of various problems, both regionally and globally.

A number of UN agencies already cooperate with the SCO, within the framework of the Economic and Social Commission for Asia and the Pacific (ESCAP), as well as the UN Office on Drugs and Crime and others. Based on the above, it can be concluded that today it is obvious that the SCO and the UN are now quite progressive in establishing ties. The implementation of ways to maintain the security and continuous development of the region is carried out through the prism of the SCO's specialized institutions as the Regional Anti-Terrorist Structure.

Speaking about Uzbekistan's active participation in SCO, it is worth noting the NATO summit in Bucharest in April 2008, where the first "President of Uzbekistan I. Karimov put forward an initiative to settle the situation in Afghanistan by non-military means. The head of Uzbekistan proposed to create a new international apparatus on the UN base to eliminate this problem - the " $6+3$ " contact group. The President also stressed the need to respect the depth of historical roots, traditional values of multinational people of Afghanistan" (President of uzbekistan i. karimov spoke at the 
Marat Zufarovich Galiullin, Farkhad Linarovich Gumarov, Ramil Rashitovich Kadyrov y Elvira Imbelevna Kamaletdinova

nato summit in Bucharest, 2020). The head of Uzbekistan suggested that this group would include countries bordering Afghanistan, Iran, China, Pakistan, Tajikistan, Turkmenistan and Uzbekistan, and given the current international situation, Russia, the US and NATO. "This group, following Karimov's idea, would have become a powerful platform for discussing and discussing ways and means of resolving this protracted situation, facilitating assistance and support from the international community for the rehabilitation of Afghanistan's economy and eliminating drug production, extremism and terrorism.

The above mentioned initiatives of the first President of the Republic of Uzbekistan were discussed for the second time during the Plenary Session of the Summit of the UN General Assembly "Millennium Development Goals" on September 20, 2010" (Millennium development goals. the united nations in the russian federation, 2020). The most important issue in the foreign policy of the Central Asian states, more precisely Uzbekistan, was to ensure regional security and stability, fight against terrorism and any manifestations thereof that could threaten the people. It is to this end that the Central Asian states cooperate closely with the United Nations, the Organization for Security and Cooperation in Europe and a number of interstate and non-governmental organizations (Abdimuminov, 2011).

It is noteworthy that the geographical States in the region are extremely interested in a balanced and balanced solution to the long-standing Afghan problem. The Declaration of the 5th SCO Heads of State Summit, held in Astana, states that SCO members have the ability and responsibility to protect the security of the Central Asian region, and calls on Western countries to leave Central Asia. This is the most visible signal given to the heads of state at the highest level (People 's Daily Online, 2020).

For many centuries, friendship, good neighborliness, trade relations, community of religious customs - all this is undoubtedly a solid basis for maintaining a peaceful environment and strengthening regional security. As it is the peace that reigns in the house of a neighbor, it is also the peace in your house. Friendly ties instruct nations to resort to all possible ways to find fragile peace in Afghanistan. The Central Asian peoples have deeply felt the tragedy of the Afghan people, sympathize with and understand their pain, and are therefore ready to build peace in the region.

\section{Acknowledgements}

The work is performed according to the Russian Government Program of Competitive Growth of Kazan Federal University. 


\section{Bibliographic References}

ABDIMUMINOV, Oybek. 2011. "UN and Central Asia: Regional Security, Peace and Cooperation on Problems of Stable Development" In: Young Scientist. Vol. 3, No. 2, pp. 68-71.

AL-QAHTANI, Mutlaq. 2006. "The Shanghai cooperation organization and the law of international organizations" In: Chinese Journal of International Law. Vol. 5, No. 1, pp. 129-147.

FROLENKOV, Villan. 2008. Political and Economic Interests in Central Asia of the Main World and Regional Actors. Shanghai Cooperation Organization: Towards New Development Boundaries: Materials Round. Tables. In-t Daln. Вост. RAS, 63-90.

KURPAYANIDI, Konstantin; URMONOV, Alex. 2016. "Modern trends in the further development of the Shanghai Cooperation Organization (SCO) in the context of globalization" In: Young scientist. Vol. 17, pp. 433-435.

MILLENNIUM DEVELOPMENT GOALS. THE UNITED NATIONS IN THE RUSSIAN FEDERATION. 2020. Available online. In: http://www. unrussia.ru/ru/millenium-development-goals. Consultation date: 27/02/2020).

OPINION: SCO REPORTS STRONG SIGNALS FOR WEST TO LEAVE CENTRAL ASIA. 2020. People 's Daily Online. Available online. In: http://en.people.cn/200507/o8/eng20050708_194907.html. Consultation date: 12/02/2020.

PRESIDENT OF UZBEKISTAN I. KARIMOV SPOKE AT THE NATO SUMMIT IN BUCHAREST. 2020. Available online. In: https://www.fergananews. $\mathrm{com} /$ news/8818. Consultation date: 22/02/2020).

SHANGHAI COOPERATION ORGANIZATION. NEW PRIORITIES OF DEVELOPMENT. 2015. Institute of Legislation and Comparative Law under the Government of the Russian Federation, Infra. Moscow, Russia.

SHANGLIN, Luan. 2006. SCO to Intensify Fight against Cross-Border Drug Crimes. China View, 2006-04.

STURGEON, Alendor. 2008. Activities of the SCO Regional Anti-Terrorist Structure to Counter Terrorism in Central Asia (2004 - 2005 years). Shanghai Cooperation Organization: Towards New Development Borders: Materials round. Tables. In-t Daln. Вост. RAS, 246-255. 
Marat Zufarovich Galiullin, Farkhad Linarovich Gumarov, Ramil Rashitovich Kadyrov y Elvira Imbelevna Kamaletdinova

SULIMANOV, Azamat; BELOGLAZOV, Alexei. 2018. "Geopolitical Interests of China in Central Asia” In: Revista San Gregorio. Vol. 25, pp. 145-149.

THE AGREEMENT BETWEEN THE GOVERNMENT OF THE REPUBLIC OF UZBEKISTAN AND THE GOVERNMENT OF THE REPUBLIC OF TAJIKISTAN "ON COOPERATION IN COMBATING TERRORISM, POLITICAL, RELIGIOUS AND OTHER EXTREMISM, ILLICIT TRAFFIC IN NARCOTIC DRUGS AND PSYCHOTROPIC SUBSTANCES”. 2020. (Khujand, 26 May 1999). Available online. In: http://www.lex.uz/docs/2194284. Consultation date: 17/02/2020.

THE AGREEMENT BETWEEN THE GOVERNMENT OF THE REPUBLIC OF UZBEKISTAN AND THE GOVERNMENT OF PEOPLE'S REPUBLIC OF CHINA ON COOPERATION IN FIGHT AGAINST TERRORISM, SEPARATISM AND EXTREMISM. 2020. (Tashkent, on September 4, 2003). Available online. In: https://buxgalter.uz/uz/ doc? id=479793_\&prodid=1_zakonodatelstvo_respubliki_Uzbekistan. Consultation date: 18.02.2020.

THE AGREEMENT BETWEEN THE STATES MEMBERS OF THE SHANGHAI COOPERATION ORGANIZATION ON THE REGIONAL ANTI-TERRORIST STRUCTURE. 2002. Official SCO website (Russian sector). Available online. In: http://rus.sectsco.org/documents/. Consultation date: 21/02/2020.

THE DECLARATION ON THE ESTABLISHMENT OF THE SHANGHAI COOPERATION ORGANIZATION. 2001. SCO Official Website (Russian Sector). Available online. In: http://rus.sectsco.org/documents. Consultation date: 21/02/2020.

UZBEKISTAN IS NOT READY TO CONSIDER THE PROPOSAL TO CREATE A SCO FTA. 2020. Available online. In: https://www.gazeta. uz/2015/12/15/azimov/. Consultation date: 22/02/2020).

UZBEKISTAN 'S INITIATIVES AND THEIR ROLE IN STRENGTHENING THE SHANGHAI COOPERATION ORGANIZATION. 2010. People 's Word of 22 September 2010. 
Vol.38 NEspecial

Esta revista fue editada en formato digital y publicada en diciembre de 2020, por el Fondo Editorial Serbiluz, Universidad del Zulia. Maracaibo-Venezuela 